\title{
Effect of irrigation at different growth stages on yield, water productivity and seed production of onion (Allium cepa $L$. CV BARI piaz-1)
}

\author{
Dilip Kumar Roy, Sujit Kumar Biswas, Abdur Razzaque Akanda, Khokan Kumer Sarker, \\ Abeda Khatun \\ Irrigation and Water Management (IWM) Division, Bangladesh Agricultural Research Institute (BARI), Gazipur, Bangladesh \\ Email address: \\ droy49@gmail.com (D. K. Roy), sujitbari@yahoo.com (S. K. Biswas), razzaquebari@gmail.com (A. R. Akanda), \\ ksarkerwrc@gmail.com (K. K. Sarker), abeda62@yahoo.com (A. Khatun)
}

To cite this article:

Dilip Kumar Roy, Sujit Kumar Biswas, Abdur Razzaque Akanda, Khokan Kumer Sarker, Abeda Khatun. Effect of Irrigation at Different Growth Stages on Yield, Water Productivity and Seed Production of Onion (Allium cepa L. CV BARI Piaz-1). American Journal of Agriculture and Forestry. Vol. 2, No. 6, 2014, pp. 256-261. doi: 10.11648/j.ajaf.20140206.14

\begin{abstract}
The study was executed in the experimental field of Irrigation and Water Management Division (IWM), Bangladesh Agricultural Research Institute (BARI), Bangladesh to investigate the effect of irrigation on onion seed yield. There were six irrigation treatments: $T_{1}=$ Irrigations at vegetative, bolting, flowering and seed formation stages, i.e., no stress, $\mathrm{T}_{2}=$ Stress at vegetative stage, $\mathrm{T}_{3}=$ Stress at bolting stage, $\mathrm{T}_{4}=$ Stress at flowering stage, $\mathrm{T}_{5}=$ Stress at seed formation stage, and $\mathrm{T}_{6}=$ Irrigations at vegetative and flowering stages (Farmers practice). Bulb to seed method was used for this study. Recommended doses of fertilizers for "BARI piaz-1" were applied for all treatments. Measured amount of irrigation water was applied at different growth stages according to the treatment combinations. Data on yield attributing characters, yield, and seasonal water use were recorded. Results showed that umbel diameter and 1000- seed weights were significantly influenced by different irrigation treatments. Irrigation treatments did not show any significant effect on other yield contributing characters studied. The highest yield $(1110.89 \mathrm{~kg} / \mathrm{ha})$ was observed from the treatment receiving irrigations at four different growth stages while the treatment in which stress was imposed at flowering stage produced the lowest seed yield $(897.70$ $\mathrm{kg} / \mathrm{ha})$. Water productivity was observed highest $\left(0.45 \mathrm{~kg} / \mathrm{m}^{3}\right)$ in treatment $\mathrm{T}_{5}$ while the lowest $\left(0.38 \mathrm{~kg} / \mathrm{m}^{3}\right) \mathrm{was}$ observed in treatment $\mathrm{T}_{4}$. The highest benefit-cost ratio (3.84) was obtained from treatment $\mathrm{T}_{1}$ while the lowest one (3.14) was found in treatment $\mathrm{T}_{4}$. The results suggested that irrigation at the flowering stage is critical for onion seed production.
\end{abstract}

Keywords: Irrigation, Growth Stages, Water Productivity, Onion, Seed Production, Allium Cepa

\section{Introduction}

Onion (Allium cepa L.) belongs to the family Alliaceae is one of the most important spices in Bangladesh [1]. Onion ranks top in respect of production and second in terms of area among the spices crops grown in Bangladesh [2]. The green leaves and flowering stalks are also edible. It is an indispensable part of the Bangladeshi diet and is commonly used both by rich and poor but domestic production does not achieve even $15 \%$ of the annual requirement [3]. Low productivity of onion in Bangladesh could be attributed to limited availability of quality seed and lack of appropriate hybrids $[1,4,5]$. The onion's seed size and weight affect the final yield [6] and improved seed contributes substantially to enhance crop yield as high as $30 \%$ [7].

Onion is a biennial crop in the temperate zones. Proper management practices are needed for onion seed production. Onion bulbs are produced in all districts of Bangladesh while seed production of onion are limited to a small number of farmer in Faridpur, Natore and Rajshahi districts [8]. Although the climate of Bangladesh is congenial to the production of high quality onion seed, farmers are not making use of modern technology for its production [5]. In Bangladesh, onion is grown as annual crop in winter season and its seeds are produced from bulb. Due to non-adaptability of exotic cultivars in agro-climatic condition of Bangladesh 
exotic cultivars generally do not bear seed production [9]. Therefore, proper management practices and production technology should be developed for successful production of onion bulb and seed from local cultivars of Bangladesh. About $8,94,000 \mathrm{~m}$. tons of onion are produced from an area of 1, 28,745 hectares [2] respect to an annual demand of about $14,50,000 \mathrm{~m}$. tons [10]. Onion is mainly used as spices in Bangladesh. The price of onion seed remains high in the season of onion cultivation. Seed is the basic and essential input for any crop production. According to Thompson [11], high quality seed is a critical input on which the effectiveness of all other inputs depends. Seeds production is a vital part in onion growing. Steady supply of good quality seeds is a prerequisite for the successful accomplishment of high production of acceptable onions as fresh bulbs or dehydrated forms either for local consumption or for export.

Onions require frequent irrigations. Soil moisture is an important factor that influences seed yield of onion. Because they extract very little water from depths beyond 24 inches; most of the water is from the top 12 inches of soil. Thus upper soil areas must be kept moist to stimulate root growth and provide adequate water for the plant. Hawthorn [12] found that high soil moisture in the seedling year performed high seed yields. Borgo et al. [13] reported that water stress during bulb sprouting and beginnings of the anthesis (period when onion flowers are fully open and functional) reduce the number of umbels and flowers per plant. However, in practice, the soil surface should not be continuously wet because it will predispose the crop to infection of root rot disease or damping off. Literature indicated that the use of irrigation could improve yield and quality of seed to a great extent [14-16]. Ali et al. [1] suggested that earthing up with 3-4 times irrigation is more effective for onion seeds production in Bangladesh.

Irrigation scheduling based on developmental stage or deficit irrigation is the technique of applying water on a timely and accurate basis to the crop, and is the key to conserving water and improving irrigation performance and sustainability of irrigated agriculture. Water availability and cultural practices may influence not only the interrelationships between seed yield and its components but also the seeds quality characteristics. A lot of work has been conducted on onion bulb production but a little information is available on onion seeds production in Bangladesh. Yield and quality of onion seed are greatly affected by soil moisture content during growth and development. Therefore, it is essential to find out the critical growth stage(s) of onion for quality seed production. Therefore, the present study was undertaken to evaluate the effects of irrigation regimes on onion seed yield and determine the critical growth stage(s) of onion for seed production.

\section{Materials and Methods}

The study was conducted during the rabi season of 20102011 at the experimental field of IWM Division, BARI, Bangladesh. The experimental site was located at $25^{\circ} 58^{\prime} \mathrm{N}$ latitude and $83^{\circ} 58^{\prime} \mathrm{E}$ longitude. The soil was silty clay loam with field capacity and bulk density, $29 \%$ and $1.44 \mathrm{gm} / \mathrm{cc}$, respectively. Onion variety "BARI piaz-1" was used to study the effect of irrigation levels on onion seed production. There are two methods of onion seed production, viz. seed to seed method and bulb to seed method. Seed to seed method is unpopular, since all the varieties are not suitable for annual seed production due to poor bolting habit and lower seed yield. Moreover, the seed production in this method is not suitable for further multiplication. For this reason, bulb to seed method was used for this study. The experiment was laid out in a randomized complete block design with three replications. The treatments were: $\mathrm{T}_{1}=$ Irrigations at vegetative, bolting, flowering and seed formation stages; $\mathrm{T}_{2}=$ Irrigations at bolting, flowering and seed formation stages; $\mathrm{T}_{3}$ $=$ Irrigations at vegetative, flowering and seed formation stages; $\mathrm{T}_{4}=$ Irrigations at vegetative, bolting and seed formation stages; $\mathrm{T}_{5}=$ Irrigations at vegetative, bolting and flowering stages; $\mathrm{T}_{6}$ - Irrigations at vegetative and flowering stages (Farmers practice).

Well-decomposed cow dung (10 ton/ha) was applied 3 days before sowing of onion bulb. Recommended dose of fertilizer (150-100-180 kg/ha N-P-K) in the form of urea, triple super phosphate and muriate of potash was applied. In addition to N-P-K, gypsum, zinc and borax were also applied at the rate of 20-3.7-1.7 kg/ha. Nitrogen was applied in two equal splits, the first along with phosphorus and potash at the time of soil preparation while the remaining half was applied during apparent flowering and umbel formation of crops. The unit plot size was $3 \mathrm{~m} \times 2 \mathrm{~m}$. Onion bulbs were planted on 06 December, 2010 in $25 \mathrm{~cm}$ apart rows maintaining plant to plant distance of $20 \mathrm{~cm}$. Bulbs were set upright and at a depth of $2.5 \mathrm{~cm}$ at 60 bulbs per plot. Measured amount of water (according to the treatments) was applied to each plot at several intervals to maintain the soil moisture content in the root zone up to field capacity. The crop was kept weed free by manual hoeing. Ten plants from each plot were selected randomly at harvest for collection of data on growth, yield components and yield.

\subsection{Estimation of Irrigation Water}

The irrigation water was applied to bring the soil moisture content at the root zone to field capacity taking into account the effective root zone depth. Before each irrigation, soil moisture was determined by digital moisture meter and Gravimetric method. Measured amount of water was applied to all treatments. The effective root zone of onion was considered as $30-40 \mathrm{~cm}$ depending on the growth stage [17]. The depth of water was determined using the following equation:

$$
d=\sum_{i=1}^{n} \frac{M_{f c i}-M_{b i}}{100} \cdot A_{i} \cdot D_{i}
$$

Where,

$d=$ net amount of water to be applied during an irrigation, 
$\mathrm{cm}$

$M_{f c i}=$ field capacity moisture content in the $i^{\text {th }}$ layer of the soil, per cent

$M_{b i}=$ moisture content before irrigation in the $i^{t h}$ layer of the soil, per cent

$A_{i}=$ bulk density of the soil in the $i^{\text {th }}$ layer

$D_{i}=$ depth of the $i^{t h}$ soil layer, cm, within the root zone, and $n=$ number of soil layers in the root zone $D$.

\subsection{Determination of Effective Rainfall}

Effective rainfall means useful or usable rainfall [17]. Effective rainfall was estimated by using the United States Department of Agriculture (USDA) Soil Conservation Method [18]. The equations are as follows:

$$
\begin{aligned}
& \mathrm{P}_{\text {effective }}=\mathrm{P}_{\text {total }}\left(125-0.2 \times \mathrm{P}_{\text {total }}\right) / 125 \text { for } \mathrm{P}_{\text {total }}<250 \mathrm{~mm} \\
& \mathrm{P}_{\text {effective }}=125+0.1 \times \mathrm{P}_{\text {total }} \text { for } \mathrm{P}_{\text {total }}>250 \mathrm{~mm}
\end{aligned}
$$

Where,

$$
\begin{aligned}
\mathrm{P}_{\text {effective }} & =\text { Effective rainfall, } \mathrm{mm} \\
\mathrm{P}_{\text {total }} & =\text { Total rainfall, } \mathrm{mm}
\end{aligned}
$$

\subsection{Harvesting and Seed Extraction}

In onion seed crop, the timing of harvest is complicated by the asynchronous pattern of seed growth and development within and between umbels. Furthermore, there is a tendency for seeds to shed soon after physiological maturity as a result of capsule dehiscence. Therefore, selection of optimum harvest time must balance the increase in the number of physiologically mature seeds in umbels over time with the decrease in seed number caused by capsule dehiscence. Although all the seed heads did not mature simultaneously, there was only one cutting. This was made sufficiently early to avoid shattering of seeds but on the other hand sufficiently late to obtain well ripen seeds. The seed heads were cut 10$15 \mathrm{~cm}$ of stem attached. The seed heads were then dried in the sun, threshed, and cleaned for seed collection. Data were analyzed statistically following MSTAT-C package program and the mean differences were evaluated by Least Significant Difference (LSD) following [19].

\section{Results and Discussion}

\subsection{Effect of Irrigation Water on Growth Parameters and Yield of Onion Seed}

The data on yield and yield attributing characters of onion seed production are incorporated in Tables 1a, 1b, 2 and 3. Data presented in tables $1 \mathrm{a}$ and $1 \mathrm{~b}$ indicate that irrigation water had no significant effect on growth parameters like plant height, number of leaves per plant, number of flower stalk per plant, length and diameter of scape, number of total and effective florets per umbel etc. There was a significant difference in the diameter of umbel due to different amount of irrigation water applied.

Table 1a. Effect of irrigation water on the growth parameters of onion for seed production

\begin{tabular}{llllllllll}
\hline Treatment & $\begin{array}{l}\text { Plant height, } \\
\text { cm }\end{array}$ & $\begin{array}{l}\text { No. of leaves/ } \\
\text { plant }\end{array}$ & $\begin{array}{l}\text { No. of flower } \\
\text { stalk/ plant }\end{array}$ & $\begin{array}{l}\text { Length of } \\
\text { scape, cm }\end{array}$ & $\begin{array}{l}\text { Diameter of } \\
\text { scape, mm }\end{array}$ & $\begin{array}{l}\text { Diameter of } \\
\text { Umbel, mm }\end{array}$ & $\begin{array}{l}\text { No. of } \\
\text { florets/ } \\
\text { umbel }\end{array}$ & $\begin{array}{l}\text { No. of } \\
\text { effective } \\
\text { florets/ umbel }\end{array}$ & $\begin{array}{l}\text { \% Effective } \\
\text { fruits set per } \\
\text { umbel }\end{array}$ \\
\hline $\mathrm{T}_{1}$ & 47.27 & 17.17 & 2.50 & 75.50 & 12.42 & 66.57 & 252.47 & 220.60 & 87.63 \\
$\mathrm{~T}_{2}$ & 43.83 & 17.33 & 2.67 & 70.20 & 11.58 & 62.37 & 240.10 & 216.90 & 90.28 \\
$\mathrm{~T}_{3}$ & 46.77 & 19.17 & 2.90 & 72.27 & 11.52 & 61.36 & 218.37 & 203.83 & 93.24 \\
$\mathrm{~T}_{4}$ & 49.10 & 17.30 & 2.40 & 77.96 & 12.55 & 65.03 & 209.83 & 187.33 & 88.80 \\
$\mathrm{~T}_{5}$ & 48.47 & 17.93 & 2.63 & 74.93 & 12.00 & 65.93 & 203.90 & 186.17 & 89.40 \\
$\mathrm{~T}_{6}$ & 49.63 & 15.27 & 2.37 & 77.00 & 12.40 & 67.37 & 217.40 & 195.10 & 91.43 \\
$\mathrm{CV}(\%)$ & 4.51 & 14.13 & 17.76 & 3.93 & 4.36 & 2.48 & 13.99 & 14.50 & 3.25 \\
$\mathrm{LSD}(0.05)$ & $\mathrm{NS}$ & $\mathrm{NS}$ & $\mathrm{NS}$ & $\mathrm{NS}$ & $\mathrm{NS}$ & 2.92 & $\mathrm{NS}$ & $\mathrm{NS}$ & $\mathrm{NS}$ \\
\hline
\end{tabular}

*Treatments: $T_{1}=$ Irrigations at vegetative, bolting, flowering and seed formation stages; $T_{2}=$ Irrigations at bolting, flowering and seed formation stages; $T_{3}=$ Irrigations at vegetative, flowering and seed formation stages; $\mathrm{T}_{4}=$ Irrigations at vegetative, bolting and seed formation stages; $\mathrm{T}_{5}=$ Irrigations at vegetative, bolting and flowering stages; $\mathrm{T}_{6}=$ Irrigations at vegetative and flowering stages (Farmers practice). CV means Coefficient of Variation; LSD indicates Least Significant Difference; NS in the last row indicates "Not Significant" while a value in this row indicates significant difference at $\mathrm{P}=5 \%$.

The number of effective florets per umbel is a very important component contributing to final seed yield. Table 1a revealed insignificant variations in the number of effective florets per umbel due to application of different amount of irrigation water. Four irrigations (treatment $T_{1}$ ) produced the highest (220.60) number of effective florets per umbel while treatment $\mathrm{T}_{5}$ (stress imposed on seed formation stage) produced the lowest (186.17) number of effective florets per umbel. Table $1 \mathrm{~b}$ revealed that irrigation water had significant effect on the quality of produced seeds. The heaviest seed $\left(2.82 \mathrm{~g} / 1000\right.$-seed) was obtained from treatment $\mathrm{T}_{1}$ and the lowest weight $(2.15 \mathrm{~g} / 1000$-seed $)$ was obtained in treatment $\mathrm{T}_{4}$. The results are in good agreement with Ali et al. [1]. 
Table 1b. Effect of irrigation water on the yield parameters of onion for seed production

\begin{tabular}{|c|c|c|c|c|c|}
\hline Treatment & No. of seeds per umbel & Seed yield per umbel, $\mathrm{g}$ & Seed yield per plant, $\mathrm{g}$ & Seed yield, Kg/ha & 1000 - seed weight, $g$ \\
\hline $\mathrm{T}_{1}$ & 788.77 & 2.22 & 5.55 & 1110.89 & 2.82 \\
\hline $\mathrm{T}_{2}$ & 743.83 & 2.10 & 5.35 & 1069.76 & 2.79 \\
\hline $\mathrm{T}_{3}$ & 739.63 & 1.95 & 5.00 & 999.03 & 2.64 \\
\hline $\mathrm{T}_{4}$ & 743.67 & 1.60 & 4.49 & 897.70 & 2.15 \\
\hline $\mathrm{T}_{5}$ & 751.70 & 1.84 & 4.81 & 962.24 & 2.45 \\
\hline $\mathrm{T}_{6}$ & 791.33 & 1.90 & 4.67 & 933.63 & 2.41 \\
\hline CV $(\%)$ & 5.47 & 12.24 & 15.95 & 15.98 & 9.30 \\
\hline $\operatorname{LSD}(0.05)$ & NS & NS & NS & NS & 0.43 \\
\hline
\end{tabular}

*Treatments: $\mathrm{T}_{1}=$ Irrigations at vegetative, bolting, flowering and seed formation stages; $\mathrm{T}_{2}=$ Irrigations at bolting, flowering and seed formation stages; $\mathrm{T}_{3}=$ Irrigations at vegetative, flowering and seed formation stages; $\mathrm{T}_{4}=$ Irrigations at vegetative, bolting and seed formation stages; $\mathrm{T}_{5}=$ Irrigations at vegetative, bolting and flowering stages; $\mathrm{T}_{6}=$ Irrigations at vegetative and flowering stages (Farmers practice). CV, Coefficient of Variation; LSD, Least Significant Difference; NS in the last row indicates "Not Significant" while a value in this row indicates significant difference at $\mathrm{P}=5 \%$.

The yield of onion seed varied among the treatments but the variation was statistically insignificant (Table $1 \mathrm{~b})$. The maximum seed yield $(1110.89 \mathrm{~kg} / \mathrm{ha})$ was found in treatment $\mathrm{T}_{1}$ and the minimum $(897.70 \mathrm{~kg} / \mathrm{ha})$ was found in treatment $\mathrm{T}_{4}$. Detailed examination of the yield components helped elucidate why higher yield was observed in the treatment experienced no stress at any growth stage (treatment $\mathrm{T}_{1}$ ). The higher number of effective florets per umbel containing relatively higher number of seeds with heavier weights appeared to have contributed to the higher seed yield in the treatment with four irrigations, i.e., no stress. Table $1 \mathrm{~b}$ revealed that the treatment experienced stress at flowering stage produced the lowest seed yield $(897.70 \mathrm{~kg} / \mathrm{ha})$. This was attributed to the fact that adequate watering conditions early in the season led to the development of an abundant leaf cover and a shallow root depth which cannot withstand water stress at later stage [20]. From the results it is clear that flowering stage of onion seed production may be considered critical. However, the role played by each of the yield contributing factors is actually the result of complex interactions with all the others and, as such, is difficult to interpret. Pejić et al. [21] reported the similar trend and concluded that onion yield was significantly influenced by irrigation.

Table 2. Days to $60 \%, 80 \%$ and $100 \%$ scape initiation, bursting and flowering

\begin{tabular}{|c|c|c|c|c|c|c|c|c|c|}
\hline \multirow{2}{*}{ Treatment } & \multicolumn{3}{|c|}{ Scape Initiation } & \multicolumn{3}{|c|}{ Bursting } & \multicolumn{3}{|c|}{ Flowering } \\
\hline & $60 \%$ & $80 \%$ & $100 \%$ & $60 \%$ & $80 \%$ & $100 \%$ & $60 \%$ & $80 \%$ & $100 \%$ \\
\hline $\mathrm{T}_{1}$ & 49.33 & 51.33 & 56.67 & 71.00 & 73.00 & 79.00 & 82.33 & 85.33 & 88.33 \\
\hline $\mathrm{T}_{2}$ & 49.33 & 51.33 & 56.33 & 71.00 & 73.00 & 79.33 & 82.67 & 85.00 & 92.00 \\
\hline $\mathrm{T}_{3}$ & 49.00 & 51.33 & 56.67 & 71.67 & 73.00 & 79.33 & 82.33 & 85.00 & 89.00 \\
\hline $\mathrm{T}_{4}$ & 49.33 & 51.00 & 57.00 & 71.00 & 73.33 & 79.33 & 82.00 & 86.00 & 90.00 \\
\hline $\mathrm{T}_{5}$ & 50.33 & 52.00 & 56.33 & 72.00 & 74.33 & 79.00 & 82.67 & 85.33 & 88.67 \\
\hline $\mathrm{T}_{6}$ & 49.67 & 51.67 & 56.00 & 72.00 & 74.00 & 79.67 & 82.33 & 85.33 & 89.33 \\
\hline CV $(\%)$ & 1.43 & 1.73 & 2.40 & 0.87 & 0.77 & 0.64 & 0.69 & 0.98 & 2.36 \\
\hline $\operatorname{LSD}(0.05)$ & NS & NS & NS & NS & NS & NS & NS & NS & NS \\
\hline
\end{tabular}

* Treatments: $\mathrm{T}_{1}=$ Irrigations at vegetative, bolting, flowering and seed formation stages; $\mathrm{T}_{2}=$ Irrigations at bolting, flowering and seed formation stages; $\mathrm{T}_{3}=$ Irrigations at vegetative, flowering and seed formation stages; $\mathrm{T}_{4}=$ Irrigations at vegetative, bolting and seed formation stages; $\mathrm{T}_{5}=$ Irrigations at vegetative, bolting and flowering stages; $\mathrm{T}_{6}=$ Irrigations at vegetative and flowering stages (Farmers practice). CV, Coefficient of Variation; LSD, Least Significant Difference; NS in the last row indicates "Not Significant" while a value in this row indicates significant difference at $\mathrm{P}=5 \%$.

Table 2 summarizes the effect of irrigation on the number of days taken to scape initiation, bursting and flowering. From table 2, it was clear that days to scape initiation, bursting and flowering were insignificant among the treatments. Days to scape initiation was found highest (57 days) in treatment $\mathrm{T}_{4}$ while the lowest (56 days) was found in treatment $\mathrm{T}_{6}$. The longest time (79.67 days) for bursting was found in treatment $T_{6}$ whereas the shortest time (79 days) was found in treatment $T_{1}$. The highest time (92 days) to flowering was found from treatment $\mathrm{T}_{4}$ while the lowest time (88.33 days) to flowering was observed in treatment $T_{1}$. Results of the current study are in accordance with Ali et al. [1] who mentioned that days to scape initiation are affected by irrigation water application.

\subsection{Water Requirement and Water Productivity}

Total water used, based on water requirement, and water productivity, based on yield $(\mathrm{kg} / \mathrm{ha})$ per unit water applied, were presented in Table 3. The total amount of irrigation water ranged from $21.52 \mathrm{~cm}$ for $T_{1}$ to $13.34 \mathrm{~cm}$ for $T_{6}$ and the number of irrigation events ranged from 4 to 2 in various treatments. The average rainfall occurred during the crop seasons was $105 \mathrm{~mm}$ and total was effective since it was much less than the soil moisture deficit. The development of crop can therefore be considered to have largely depended on the irrigation water. Total water use varied with the variation of the amount of irrigation water applied to the plots. Total water use was found maximum $(28.77 \mathrm{~cm})$ in treatment $T_{1}$ 
and minimum $(20.65 \mathrm{~cm})$ in farmer's practice treatment $T_{6}$. The highest amount of irrigation water $(21.52 \mathrm{~cm})$ was required in the treatment that received a total four irrigations at all stages. The quantities of water applied during each irrigation event were low under this treatment. Quantity of water applied during irrigation increased when interval between consecutive irrigation events was increased. The water use pattern by different treatments was like that as higher the frequency of irrigation the less the amount of water needed in each irrigation. This was due to the existence of more soil moisture in the treatments, in which intervals are short. The highest water productivity $\left(0.45 \mathrm{~kg} / \mathrm{m}^{3}\right)$ was obtained in treatment $T_{5}$ while the lowest $\left(0.38 \mathrm{~kg} / \mathrm{m}^{3}\right)$ was found in treatment $\mathrm{T}_{4}$.

Table 3. Component of water requirement and water productivity in different irrigation treatments

\begin{tabular}{|c|c|c|c|c|c|c|c|}
\hline Treatment & No. of irrigation & $\begin{array}{l}\text { Amount of total } \\
\text { irrigation, cm }\end{array}$ & $\begin{array}{l}\text { Effective } \\
\text { rainfall, cm }\end{array}$ & $\begin{array}{l}\text { Soil moisture } \\
\text { contribution, cm }\end{array}$ & $\begin{array}{l}\text { Total water } \\
\text { used, cm }\end{array}$ & $\begin{array}{l}\text { Yield, } \\
\text { kg/ha }\end{array}$ & $\begin{array}{l}\text { Water Productivity, } \\
\mathrm{kg} / \mathrm{m}^{3}\end{array}$ \\
\hline 1 & 2 & 3 & 4 & 5 & $6=3+4+5$ & 7 & $8=7 / 6$ \\
\hline $\mathrm{T}_{1}$ & 4 & 21.52 & 10.50 & -3.25 & 28.77 & 1110.89 & 0.39 \\
\hline $\mathrm{T}_{2}$ & 3 & 18.94 & 10.50 & -2.91 & 26.53 & 1069.76 & 0.40 \\
\hline $\mathrm{T}_{3}$ & 3 & 19.32 & 10.50 & -3.28 & 26.54 & 999.03 & 0.39 \\
\hline $\mathrm{T}_{4}$ & 3 & 16.10 & 10.50 & -2.85 & 23.75 & 897.70 & 0.38 \\
\hline $\mathrm{T}_{5}$ & 3 & 15.07 & 10.50 & -3.24 & 22.33 & 962.24 & 0.43 \\
\hline $\mathrm{T}_{6}$ & 2 & 13.34 & 10.50 & -3.19 & 20.65 & 933.63 & 0.45 \\
\hline
\end{tabular}

* Treatments: $\mathrm{T}_{1}=$ Irrigations at vegetative, bolting, flowering and seed formation stages; $\mathrm{T}_{2}=$ Irrigations at bolting, flowering and seed formation stages; $\mathrm{T}_{3}=$ Irrigations at vegetative, flowering and seed formation stages; $\mathrm{T}_{4}=$ Irrigations at vegetative, bolting and seed formation stages; $\mathrm{T}_{5}=$ Irrigations at vegetative, bolting and flowering stages; $\mathrm{T}_{6}=$ Irrigations at vegetative and flowering stages (Farmers practice).

\section{Economic Comparison}

Data pertaining to economic comparison is presented in Table 4. All the variable costs except the irrigation costs were similar in all the treatments. The highest net margin (Tk. 657332) and benefit-cost ratio (3.84) were found in treatment $\mathrm{T}_{1}$ while the lowest benefit-cost ratio (3.14) was obtained from treatment $\mathrm{T}_{4}$. This may attributed to the fact that treatment $T_{1}$ experienced no water stress during the growing season and thus produced maximum seed yield and highest net margin and benefit-cost ratio. On the other hand, the lowest net margin and benefit-cost ratio of treatment $T_{4}$ may be attributed to the stress imposed on the flowering stage which is the critical stage for onion seed production.

Table 4. Economic analysis of onion seed production under different irrigation treatments

\begin{tabular}{|c|c|c|c|c|c|c|}
\hline \multirow{2}{*}{ Indicators } & \multicolumn{6}{|c|}{ Treatments } \\
\hline & $\mathrm{T}_{1}$ & $\mathbf{T}_{2}$ & $\mathbf{T}_{3}$ & $\mathbf{T}_{4}$ & $\mathbf{T}_{5}$ & $T_{6}$ \\
\hline \multicolumn{7}{|l|}{ Variable costs (Tk./ha) } \\
\hline Land preparation & 7000 & 7000 & 7000 & 7000 & 7000 & 7000 \\
\hline Labor & 54000 & 54000 & 54000 & 54000 & 54000 & 54000 \\
\hline Fertilizers & 25230 & 25230 & 25230 & 25230 & 25230 & 25230 \\
\hline Manure & 20000 & 20000 & 20000 & 20000 & 20000 & 20000 \\
\hline Onion bulb & 100000 & 100000 & 100000 & 100000 & 100000 & 100000 \\
\hline Irrigation & 9150 & 8053 & 8214 & 6845 & 6407 & 5672 \\
\hline Total cost (Tk./ha) & 231380 & 230283 & 230444 & 229075 & 228637 & 227902 \\
\hline \multicolumn{7}{|l|}{ Gross margin (Tk./ha) } \\
\hline Onion seed & 888712 & 855808 & 799224 & 718160 & 769792 & 746904 \\
\hline Net margin (Tk./ha) & 657332 & 625525 & 568780 & 489085 & 541155 & 519002 \\
\hline $\mathrm{BCR}$ & 3.84 & 3.72 & 3.47 & 3.14 & 3.37 & 3.28 \\
\hline
\end{tabular}

* $1 \mathrm{Tk}$. is approximately US\$ 0.125

\section{Conclusion}

The yield of onion seed was reasonably affected by the irrigation regimes. Four irrigations at different growth stages contributed to the increased seed yield of onion due to the availability of adequate moisture in the root zone during the critical growth stages. Depending on the quantity and timing of irrigation, the applied irrigation imparted different degrees of influence on the various components of growth and yield parameters. The yield was the least when stress was imposed on the flowering stage, irrespective of the amount of water applied. Therefore, it can be concluded that flowering stage is the most critical to irrigation water for onion seed production in the study area. Three irrigations including one at flowering stage may be used without any significant yield loss for onion seed production in the study area. So, three irrigations each at vegetative, flowering and seed formation stage may be the optimum and feasible irrigation scheduling for onion seed production under irrigation water shortage situation.

\section{Acknowledgements}

The authors would like to thank Irrigation and Water Management Division, Bangladesh Agricultural Research Institute, Bangladesh for providing support and expertise for 
carrying out the study. The authors gratefully acknowledge the financial support of Bangladesh Agricultural Research Institute to meet the full research expenses for this study.

\section{References}

[1] Ali MK, Alam MF, Alam MN, Islam MS, Khandaker SMAT (2007). Effect of nitrogen and potassium level on yield and quality of seed production of onion. J. Appl. Sci. Res. 3:188999.

[2] BBS (2008). Monthly (February) Statistical Bulletin of Bangladesh. Bangladesh Bureau of Statistics, Ministry of Planning, Government of the People's Republic of Bangladesh, Dhaka. 66 p.

[3] Hossain AKMA, Islam J (1994). Status of Allium production in Bangladesh. Acta Hort. 358: 33-36.

[4] Tomar BS, Singh B, Hassan M (2004). Effect of irrigation methods on seed yield and seed quality in onion cv. Pusa Madhavi. Seed Res. 32: 72-81.

[5] Bokshi AI, Mondal MF, Pramanik MHR (1989). Effect of nitrogen and phosphorus nutrition on the yield and quality of onion seeds. Bangladesh Hort. 17(2): 30-35.

[6] Gamiely S, Smittle DA, Mills HA, Banna GI (1990). Onion seed size, weight, and element content affect germination and bulb yield. Hort. Sci. 25: 522-523.

[7] Shaikh AM, Vyakaranahal BS, Shekhargouda M, Dharmatti PR (2002). Influence of bulb size and growth regulators on growth, seed yield and quality of onion cv. Nasik Red. Seed Res. 30: 223-229.

[8] Rahim MA, Amin MMU, Haider MA (1993). Onion seed production technology in Bangladesh. Allium improvement Newsletter, USA 3: 26-33.

[9] Rahim MA, Hussain A, Siddique MA (1982). Seed production ability of three onion cultivars. Bangladesh Hort. 10: 31-38.

[10] Anonymous (2006). Action plan for increasing the productivity of spices 2006-2009. National technical working group. Ministry of Agriculture, Govt. of the People's Republic of Bangladesh.

[11] Thompson JR (1979). An Introduction to Seed Technology. Leonard Hill Books Ltd., London, pp. 19.

[12] Hawthron LR (1951). Studies on soil moisture and spacing of seed crops of carrot and onion. USDA, Circular no. 852.

[13] Borgo R, Stahlsehmidt DM, Tizio RM (1993). Preliminary study on water requirements of onion $\mathrm{cv}$. Valcatarce in relation to seed production. Agri. Scientia. 10: 3-9.

[14] Brown MJ, Wright JL, Khol RA (1977). Onion seed yield and quality as affected by irrigation management. Agron. J. 34(8): 260-268.

[15] Shasha ANS, Campbell WF, Nye WP (1986). Effect of fertilizer and moisture on seed yield of onion. Hort. Sci., 11(4): 425-426.

[16] Bhonde SR, Lecehiman R, Srivastava KJ, Ram L (1989). Effect of spacing and levels of nitrogen on seed yield of onion. Seed and Farms, 15(1): 21-22.

[17] Michael AM (1985). Irrigation: Theory and Practice. Vikas Publishing House Private Limited. New Delhi, India p.539.

[18] Smith M (1992). CROPWAT, A computer programme. Irrigation Planning and Management, FAO Irrigation and Drainage Paper 46. Rome. Italy.

[19] Gomez KA, Gomez AA (1984). Statistical Procedures for Agricultural Research. John Wiley and Sons Inc. New York p. 214.

[20] Bazza M (1999). Improving irrigation management practices with water-deficit irrigation. In: Kirda C, Moutonnet P, Hera C, Nielsen DR (Eds.), Crop Yield Response to Deficit Irrigation. Kluwer Academic Publishers, Dordrecht, the Netherlands, pp. 49-71.

[21] Pejić B, Borivoj Pejić J, Milić S, Ignjatović-Ćupina A, Krstić D, Ćupina B (2011). Effect of irrigation schedules on yield and water use of onion (Allium cepa L.). African J. Biotech. 10(14): 2644-2652. 